\title{
Pharmaceutical treatment of acute bipolar depression
} Konstantinos N Fountoulakis ${ }^{1,2}$

\author{
Addresses: ${ }^{1} 3^{\text {rd }}$ Department of Psychiatry, School of Medicine, Aristotle University of Thessaloniki, Thessalonika 54621, Greece; \\ ${ }^{2} 6$ Odysseos Str (1 ${ }^{\text {st }}$ Parodos Ampelonon Str), Pylaia 55535, Thessaloniki, Greece \\ Email: kfount@med.auth.gr
}

FI000 Medicine Reports 2010, 2:47 (doi:10.3410/M2-47)

The electronic version of this article is the complete one and can be found at: http://fl000.com/reports/medicine/content/2/47

\begin{abstract}
The treatment of bipolar depression is one of the most challenging fields in contemporary psychiatry. The best data concern the antipsychotics quetiapine and the olanzapine-fluoxetine combination. However, the usefulness of antidepressants in bipolar depression remains controversial; positive data are available for fluoxetine but negative results have been published for paroxetine. Accumulated knowledge so far suggests that bipolar patients need continuous administration of an antimanic agent even during the acute depressive phase. Although our knowledge is indeed limited, the development of guidelines for polypharmacy is necessary and should be done as soon as possible.
\end{abstract}

\section{Introduction and content}

The treatment of bipolar disorder is complex and full of caveats for the clinician [1-4]. An important problem in the gathering of scientific evidence lies in the low reliability and validity of diagnosis. Another problem is that specific and different treatments need to be considered separately for manic, hypomanic, mixed and bipolar depression episodes, as well as for unipolar depression. This article will comment on the available hard data (randomized trials) for the treatment of bipolar depression and suggest future directions for research.

Older studies conducted throughout the 1970s and 1980 s on treatment of bipolar disorder reported positive effects for lithium [5], carbamazepine [6], amitriptiline $[5]$, imipramine $[7,8]$ and fluoxetine [9-11], however, the studies were small and suffered from a number of methodological drawbacks. Results from add-on studies with imipramine as an adjunctive therapy to lithium were negative $[7,8,12]$.

Within the last 10 years, several phase III clinical studies of lamotrigine (SCA100223, SCA30924, SCA40910, SCAA2010 and SCAB2001) have demonstrated a lack of efficacy for this agent in the treatment of bipolar disorder [13]. There were only two small studies reporting a positive effect of valproate in bipolar I patients $[14,15]$, while on the contrary, the efficacy of the olanzapine-fluoxetine combination (OFC) against bipolar I depression has been well documented [16,17]. There has been concern about the effect of olanzapine monotherapy on the 'depressive core' of symptoms, however, it is certain that patients receiving this treatment manifest a significant improvement in symptoms 'peripheral' to those of depression, such as insomnia, anxiety and loss of appetite $[18,19]$. It has been reported that the OFC is more effective than olanzapine monotherapy [17] and also improves many secondary indices [20].

One study without a placebo arm suggested both paroxetine and venlafaxine could be effective for the treatment of bipolar depressed patients [21]. Another compared imipramine and paroxetine with placebo as an add-on to an ongoing lithim regimen and reported that these antidepressants were beneficial for patients with low (but not high) serum levels of lithium [22]. Other reports suggest that adding venlafaxine, sertraline or buproprion to a mood stabilizer increases the response rate [23-25]. Similar findings were reported for paroxetine [26] and citalopram [27]. Adding inositol [28] or 
modafinil [29] to a mood stabilizer could also be useful in the treatment of bipolar depression.

\section{Recent advances}

During the last 3 years, there have been some important insights from newly available data. For example, recent negative data has emerged for drugs that had previously shown efficacy in older studies, such as monotherapy with lithium [30], paroxetine [31] and aripiprazole [32], and there have been equivocal results for valproate: two randomized controlled trials (RCTs) on the extendedrelease form of valproate reported one positive and one negative result; neither study was published (for reviews, see $[33,34])$.

Quetiapine was, however, reported to be effective at dosages of both $600 \mathrm{mg} /$ day and $300 \mathrm{mg} /$ day, and produced response rates of $58.2 \%$ and $57.6 \%$, respectively (versus $36.1 \%$ for placebo), and remission rates of $52.9 \%$ in both the treated groups (versus $28.4 \%$ for placebo) [35]. It is important to note that quetiapine significantly improved all the Montgomery-Åsberg Depression Rating Scale (MADRS) items corresponding to the core symptoms of depression. Post-hoc analysis suggests $300 \mathrm{mg}$ and $600 \mathrm{mg}$ are equally effective; despite there being a small difference in the effect size [35,36], they both improved secondary measures including quality of life indices [37]. Similar results were obtained from two more recent RCTs [30,31]. Another study reported that an extended-release form of quetiapine at $300 \mathrm{mg}$ daily was significantly more effective than placebo for bipolar I depression throughout the 8-week study, with significance observed as early as day 7 [38].

In a recent double-blind, placebo-controlled study, adding an antidepressant (either buproprion or paroxetine) to a mood stabilizer in 179 bipolar depressed patients was not significantly more beneficial than placebo after 26 weeks of treatment, and the recovery rates $23.5 \%$ in the antidepressant group versus $27.3 \%$ in the placebo group) and switch rates to mania were similar [39]. Thus, this study does not support the usefulness of adjunctive antidepressant therapy. However, these data should be read with caution because although paroxetine played a significant role in the design, it has since been shown to be no more effective than placebo [31]. A more recent study reported that adding lamotrigine to lithium was more effective than placebo in patients with bipolar depression [40]. Another recent 8-week trial studied 52 incomplete responders treated with carbamazepine or oxcarbazepine (600-1200 mg daily) during maintenance treatment with lithium [41]. Although this trial focused on patients in the 'maintenance' phase, the design and the results are more relevant to the acute depressive phase because the study sample included depressed patients. Both groups improved with the addition of either drug but those receiving oxcarbazepine improved significantly more in terms of their MADRS and Hamilton Depression Rating Scale (HDRS)-21 scores [41]. Another study reported that adding venlafaxine, sertraline or buproprion to a mood stabilizer increases the response rate [23].

Several reviews and meta-analytic studies of the literature are currently available. Some suggest that only quetiapine - and to a lesser extent, olanzapine show efficacy as a monotherapy for bipolar depression [42-44]. However, two meta-analyses of four randomized placebo-controlled trials (of 6 and 8 week duration) with a total sample size of 142 patients suggested that divalproex could also be efficacious in acute bipolar depression, with response rates of $39.3 \%$ for divalproex versus $17.5 \%$ for placebo. Remission rates were $40.6 \%$ versus $24.3 \%$, respectively [33], with an effect size $d$ equal to 0.35 [34]. The meta-analyisis of the five 'negative' trials of lamotrigine monotherapy (1072 patients) reported that lamotrigine was superior to placebo in people with an HDRS score of greater than 24 but not in people with an HDRS score of less than or equal to 24 [45]. The meta-analysis of data on paroxetine and monoamine oxidase inhibitors (MAOIs) in 52 patients confirmed that the effectiveness of paroxetine was unacceptably low, but rates of recovery with MAOIs were significantly higher than the recovery rate with paroxetine [46].

\section{Implications for clinical practice}

Classically, the treatment of bipolar illness includes the use of the so-called mood stabilizers (lithium and specific anticonvulsants), antipsychotics, and antidepressants. Recent data dispute the efficacy of some of these agents against bipolar depression. Only quetiapine and the OFC are currently considered to be effective and thus have been approved for the treatment of acute bipolar depression $[17,47,48]$. Typical antipsychotics (haloperidol, chlorpromazine and perphenazine) seem to have some efficacy against acute mania but they also seem to predispose patients to manifest dysphoria or depression $[49,50]$. The dispute concerning the usefulness of antidepressants continues; clinicians should be cautious in their use and avoid prescribing them as monotherapy [1]. It is important to bear in mind that the only positive data available for the use of antidepressants in treating bipolar disorder are for fluoxetine; strong negative data still exist for paroxetine. Since, in real life, the majority of bipolar patients do not do well on monotherapy, several combination therapies and add-on agents have been tested $[23,40,41]$ that the clinician should become familiar with. 
Some of the recommendations above are in relative contrast to everyday clinical practice where clinicians do not tailor their choice of antidepressant to a specific type of depression and tend to use typical antipsychotics against mania. The chronicity of bipolar depression and its relative refractoriness to treatment might be the cause of this discrepancy. However, treating patients as if there is a 'class effect' for drugs might iatrogenically worsen the long-term course of the illness in some patients.

When the clinician is treating a depressed bipolar patient, it is clear that the first step should be the use of agents with proven efficacy (from placebo-controlled double-blind studies) against this condition. However, it is likely that most patients will fail with such a treatment and the clinician will be left with no hard data to rely on. In this case, the clinician should avoid treatments with a proven worsening effect on the long-term outcome of the disease. Additionally, psychoeducation could constitute a useful tool to treat bipolar depression, along with family-focused psychoeducation and cognitive-behavioral therapy [51].

\section{Abbreviations}

HDRS, Hamilton Depression Rating Scale; MADRS, Montgomery-Åsberg Depression Rating Scale; MAOI, monoamine oxidase inhibitor; OFC, olanzapine-fluoxetine combination; RCT, randomized controlled trial.

\section{Competing interests}

The author has received support comprising travel and accommodation expenses from various pharmaceutical companies in order to participate in medical congresses. He has also received honoraria for lectures from AstraZeneca, Janssen-Cilag, Eli Lilly and a research grant from the Pfizer Foundation. He is member of the board of Wyeth for desvenlafaxine and Bristol-Myers Squibb for aripiprazole in bipolar disorder.

\section{References}

I. Fountoulakis KN, Vieta E, Sanchez-Moreno J, Kaprinis SG, Goikolea JM, Kaprinis GS: Treatment guidelines for bipolar disorder: a critical review. J Affect Disord 2005, 86: I-I0.

2. Fountoulakis KN, Magiria S, Siamouli M, Panagiotidis P, Nimatoudis I, lacovides A, Kaprinis GS: A seven- year follow-up of an extremely refractory bipolar I patient. CNS Spectr 2007, 1 2:733-4.

3. Fountoulakis KN, Vieta E, Siamouli M, Valenti M, Magiria S, Oral T, Fresno D, Giannakopoulos P, Kaprinis GS: Treatment of bipolar disorder: a complex treatment for a multi-faceted disorder. Ann Gen Psychiatry 2007, 6:27.

4. Fountoulakis KN, Grunze H, Panagiotidis P, Kaprinis G: Treatment of bipolar depression: an update. J Affect Disord 2008, 109:2I-34.

5. Glen Al, Johnson AL, Shepherd M: Continuation therapy with lithium and amitriptyline in unipolar depressive illness: a randomized, double-blind, controlled trial. Psychol Med 1984, 14:37-50.
6. Ballenger JC, Post RM: Carbamazepine in manic-depressive illness: a new treatment. Am J Psychiatry 1980, 137:782-90.

7. Prien RF, Klett CJ, Caffey EM Jr: Lithium carbonate and imipramine in prevention of affective episodes. A comparison in recurrent affective illness. Arch Gen Psychiatry 1973, 29:420-5.

8. Prien RF, Kupfer DJ, Mansky PA, Small JG, Tuason VB, Voss CB, Johnson WE: Drug therapy in the prevention of recurrences in unipolar and bipolar affective disorders. Report of the NIMH Collaborative Study Group comparing lithium carbonate, imipramine, and a lithium carbonate-imipramine combination. Arch Gen Psychiatry 1984, 41:1096-104.

9. Amsterdam JD, Garcia-España F, Fawcett J, Quitkin FM, Reimherr FW, Rosenbaum JF, Schweizer E, Beasley C: Efficacy and safety of fluoxetine in treating bipolar II major depressive episode. J Clin Psychopharmacol 1998, 18:435-40.

10. Amsterdam JD, Shults J: Comparison of fluoxetine, olanzapine, and combined fluoxetine plus olanzapine initial therapy of bipolar type I and type II major depression-lack of manic induction. J Affect Disord 2005, 87:121-30.

II. Cohn JB, Collins G, Ashbrook E, Wernicke JF: A comparison of fluoxetine imipramine and placebo in patients with bipolar depressive disorder. Int Clin Psychopharmacol 1989, 4:313-22.

12. Kane JM, Quitkin FM, Rifkin A, Ramos-Lorenzi JR, Nayak DD, Howard A: Lithium carbonate and imipramine in the prophylaxis of unipolar and bipolar II illness: a prospective, placebo-controlled comparison. Arch Gen Psychiatry 1982, 39:1065-9.

13. Goldsmith DR, Wagstaff AJ, Ibbotson T, Perry CM: Lamotrigine: a review of its use in bipolar disorder. Drugs 2003, 63:2029-50.

14. Davis LL, Bartolucci A, Petty F: Divalproex in the treatment of bipolar depression: a placebo-controlled study. J Affect Disord 2005, 85:259-66.

15. Ghaemi SN, Gilmer WS, Goldberg JF, Zablotsky B, Kemp DE, Kelley ME, Bauer AD, Fleck J, Filkowski MM, Stan VA, Dunn RT: Divalproex in the treatment of acute bipolar depression: a preliminary double-blind, randomized, placebo-controlled pilot study. J Clin Psychiatry 2007, 68:1840-4.

16. Brown EB, McElroy SL, Keck PE Jr, Deldar A, Adams DH, Tohen M, Williamson DJ: A 7-week, randomized, double-blind trial of olanzapine/fluoxetine combination versus lamotrigine in the treatment of bipolar I depression. J Clin Psychiatry 2006, 67:1025-33.

17. Tohen M, Vieta E, Calabrese J, Ketter TA, Sachs G, Bowden C, Mitchell PB, Centorrino F, Risser R, Baker RW, Evans AR, Beymer K, Dube S, Tollefson GD, Breier A: Efficacy of olanzapine and olanzapine-fluoxetine combination in the treatment of bipolar I depression. Arch Gen Psychiatry 2003, 60:1079-88.

18. Bech P: Meta-analysis of placebo-controlled trials with mirtazapine using the core items of the Hamilton Depression Scale as evidence of a pure antidepressive effect in the shortterm treatment of major depression. Int J Neuropsychopharmacol 200I, 4:337-45.

19. Lecrubier $Y$, Bech $P$ : The Ham $D(6)$ is more homogenous and as sensitive as the Ham D(17). Eur Psychiatry 2007, 22:252-5.

20. Shi L, Namjoshi MA, Swindle R, Yu X, Risser R, Baker RW, Tohen M: Effects of olanzapine alone and olanzapine/fluoxetine combination on health-related quality of life in patients with bipolar depression: secondary analyses of a double-blind, placebocontrolled, randomized clinical trial. Clin Ther 2004, 26:125-34.

21. Vieta E, Martinez-Arán A, Goikolea JM, Torrent C, Colom F, Benabarre A, Reinares M: A randomized trial comparing paroxetine and venlafaxine in the treatment of bipolar depressed patients taking mood stabilizers. J Clin Psychiatry 2002, 63:508-12.

22. Nemeroff CB, Evans DL, Gyulai L, Sachs GS, Bowden CL, Gergel IP, Oakes R, Pitts CD: Double-blind, placebo-controlled comparison of imipramine and paroxetine in the treatment of bipolar depression. Am J Psychiatry 200I, 158:906-I2. 
23. Altshuler LL, Post RM, Hellemann G, Leverich GS, Nolen WA Frye MA, Keck PE Jr, Kupka RW, Grunze H, McElroy SL, Sugar CA, Suppes T: Impact of antidepressant continuation after acute positive or partial treatment response for bipolar depression: a blinded, randomized study. J Clin Psychiatry 2009, 70:450-7.

24. Post RM, Altshuler LL, Frye MA, Suppes T, Rush AJ, Keck PE Jr, McElroy SL, Denicoff KD, Leverich GS, Kupka R, Nolen WA: Rate of switch in bipolar patients prospectively treated with secondgeneration antidepressants as augmentation to mood stabilizers. Bipolar Disord 200I, 3:259-65.

25. Post RM, Altshuler LL, Leverich GS, Frye MA, Nolen WA, Kupka RW, Suppes T, McElroy S, Keck PE, Denicoff KD, Grunze H, Walden J, Kitchen CM, Mintz J: Mood switch in bipolar depression: comparison of adjunctive venlafaxine, bupropion and sertraline. Br J Psychiatry 2006, 189:124-31.

26. Young LT, Joffe RT, Robb JC, MacQueen GM, Marriott M, PatelisSiotis I: Double-blind comparison of addition of a second mood stabilizer versus an antidepressant to an initial mood stabilizer for treatment of patients with bipolar depression. Am J Psychiatry 2000, 157:124-6.

27. Schaffer A, Zuker P, Levitt A: Randomized, double-blind pilot trial comparing lamotrigine versus citalopram for the treatment of bipolar depression. J Affect Disord 2006, 96:95-9.

28. Eden Evins A, Demopulos C, Yovel I, Culhane M, Ogutha J, Grandin LD, Nierenberg AA, Sachs GS: Inositol augmentation of lithium or valproate for bipolar depression. Bipolar Disord 2006, 8:168-74.

29. Frye MA, Grunze H, Suppes T, McElroy SL, Keck PE Jr, Walden J, Leverich GS, Altshuler LL, Nakelsky S, Hwang S, Mintz J, Post RM: A placebo-controlled evaluation of adjunctive modafinil in the treatment of bipolar depression. Am J Psychiatry 2007, 164:1242-9.

30. Young AH, McElroy SL, Bauer M, Philips N, Chang W, Olausson B, Paulsson B, Brecher M; EMBOLDEN I (Trial 00I) Investigators: A double-blind, placebo-controlled study of quetiapine and lithium monotherapy in adults in the acute phase of bipolar depression (EMBOLDEN I). J Clin Psychiatry 2010, 71:150-62.

31. McElroy SL, Weisler RH, Chang W, Olausson B, Paulsson B, Brecher M, Agambaram V, Merideth C, Nordenhem A, Young AH; EMBOLDEN II (Trial DI447C00 I34) Investigators: A double-blind, placebo-controlled study of quetiapine and paroxetine as monotherapy in adults with bipolar depression (EMBOLDEN II). J Clin Psychiatry 2010, 7 I:163-74.

32. Thase ME, Jonas A, Khan A, Bowden $\mathrm{CL}$, Wu X, McQuade RD, Carson WH, Marcus RN, Owen R: Aripiprazole monotherapy in nonpsychotic bipolar I depression: results of 2 randomized, placebo-controlled studies. J Clin Psychopharmacol 2008, 28: I3-20.

33. Bond DJ, Lam RW, Yatham LN: Divalproex sodium versus placebo in the treatment of acute bipolar depression: $A$ systematic review and meta-analysis. J Affect Disord 2009, [Epub ahead of print].

34. Smith LA, Cornelius VR, Azorin JM, Perugi G, Vieta E, Young AH, Bowden CL: Valproate for the treatment of acute bipolar depression: Systematic review and meta-analysis. J Affect Disord 2010, 122:1-9.

35. Cookson J, Keck PE Jr, Ketter TA, Macfadden W: Number needed to treat and time to response/remission for quetiapine monotherapy efficacy in acute bipolar depression: evidence from a large, randomized, placebo-controlled study. Int Clin Psychopharmacol 2007, 22:93-100.

36. Weisler RH, Calabrese JR, Thase ME, Arvekvist R, Stening G, Paulsson B, Suppes T: Efficacy of quetiapine monotherapy for the treatment of depressive episodes in bipolar I disorder: a post hoc analysis of combined results from 2 double-blind, randomized, placebo-controlled studies. J Clin Psychiatry 2008, 69:769-82.

37. Endicott J, Rajagopalan K, Minkwitz M, Macfadden W; BOLDER Study Group: A randomized, double-blind, placebo-controlled study of quetiapine in the treatment of bipolar I and II depression: improvements in quality of life. Int Clin Psychopharmacol 2007, 22:29-37.
38. Suppes T, Datto C, Minkwitz M, Nordenhem A, Walker C, Darko D: Effectiveness of the extended release formulation of quetiapine as monotherapy for the treatment of acute bipolar depression. J Affect Disord 2010, I2I:106-15.

39. Sachs GS, Nierenberg AA, Calabrese JR, Marangell LB, Wisniewski SR, Gyulai L, Friedman ES, Bowden CL, Fossey MD, Ostacher MJ, Ketter TA, Patel J, Hauser P, Rapport D, Martinez JM, Allen MH, Miklowitz DJ, Otto MW, Dennehy EB, Thase ME: Effectiveness of adjunctive antidepressant treatment for bipolar depression. N Engl J Med 2007, 356: I7II-22.

FI000 Factor 6.0 Must Read

Evaluated by Rudolf Uher 15 Jun 2007

40. van der Loos ML, Mulder PG, Hartong EG, Blom MB, Vergouwen AC, de Keyzer HJ, Notten PJ, Luteijn ML, Timmermans MA, Vieta E, Nolen WA; LamLit Study Group: Efficacy and safety of lamotrigine as add-on treatment to lithium in bipolar depression: a multicenter, double-blind, placebo-controlled trial. J Clin Psychiatry 2009, 70:223-31.

4I. Juruena MF, Ottoni GL, Machado-Vieira R, Carneiro RM, Weingarthner N, Marquardt AR, Fleig SS, Broilo L, Busnello EA: Bipolar I and II disorder residual symptoms: oxcarbazepine and carbamazepine as add-on treatment to lithium in a double-blind, randomized trial. Prog Neuropsychopharmacol Biol Psychiatry 2009, 33:94-9.

42. Cruz N, Sanchez-Moreno J, Torres F, Goikolea JM, Valentí M, Vieta E: Efficacy of modern antipsychotics in placebo-controlled trials in bipolar depression: a meta-analysis. Int J Neuropsychopharmacol 2010, 13:5-14.

43. Mclntyre RS, Muzina DJ, Adams A, Lourenco MT, Law CW, Soczynska JK, Woldeyohannes HO, Nathanson J, Kennedy SH: Quetiapine XR efficacy and tolerability as monotherapy and as adjunctive treatment to conventional antidepressants in the acute and maintenance treatment of major depressive disorder: a review of registration trials. Expert Opin Pharmacother 2009, 10:3061-75.

44. Tamayo JM, Zarate CA, Vieta E, Vázquez G, Tohen M: Level of response and safety of pharmacological monotherapy in the treatment of acute bipolar I disorder phases: a systematic review and meta-analysis. Int J Neuropsychopharmacol 2010, 4:I-20.

45. Geddes JR, Calabrese JR, Goodwin GM: Lamotrigine for treatment of bipolar depression: independent meta-analysis and meta-regression of individual patient data from five randomised trials. Br J Psychiatry 2009, 194:4-9.

46. Mallinger AG, Frank E, Thase ME, Barwell MM, Diazgranados N, Luckenbaugh DA, Kupfer DJ: Revisiting the effectiveness of standard antidepressants in bipolar disorder: are monoamine oxidase inhibitors superior? Psychopharmacol Bull 2009, 42:64-74.

47. Calabrese JR, Keck PE Jr, Macfadden W, Minkwitz M, Ketter TA, Weisler RH, Cutler AJ, McCoy R, Wilson E, Mullen J: A randomized, double-blind, placebo-controlled trial of quetiapine in the treatment of bipolar I or II depression. Am J Psychiatry 2005, 162:135I-60.

48. Thase ME, Macfadden W, Weisler RH, Chang W, Paulsson B, Khan A, Calabrese JR; BOLDER II Study Group: Efficacy of quetiapine monotherapy in bipolar I and II depression: a double-blind, placebo-controlled study (the BOLDER II study). J Clin Psychopharmacol 2006, 26:600-9.

49. Tohen M, Goldberg JF, Gonzalez-Pinto Arrillaga AM, Azorin JM, Vieta E, Hardy-Bayle MC, Lawson WB, Emsley RA, Zhang F, Baker RW, Risser RC, Namjoshi MA, Evans AR, Breier A: A I 2-week, doubleblind comparison of olanzapine vs haloperidol in the treatment of acute mania. Arch Gen Psychiatry 2003, 60:1218-26.

50. Zarate CA Jr, Tohen M: Double-blind comparison of the continued use of antipsychotic treatment versus its discontinuation in remitted manic patients. Am J Psychiatry 2004, |61:|69-7|.

5I. Scott J, Colom F, Vieta E: A meta-analysis of relapse rates with adjunctive psychological therapies compared to usual psychiatric treatment for bipolar disorders. Int J Neuropsychopharmacol 2007, 10:123-9. 